\title{
The Effect of Inoculation on Growth, Nodulation and Nitrogen in Annual Clover Cultivars Grown at Two Mediterranean Locations of Sardinia, Italy
}

\author{
Leonardo SULAS ${ }^{1}$, Giovanni A. RE ${ }^{1}$, Mauro SALIS ${ }^{1}$, Giovanni GARAU², \\ Maria SITZIA ${ }^{3}$, Lorenzo SALIS ${ }^{3}$

\begin{abstract}
${ }^{1}$ Consiglio Nazionale delle Ricerche, Istituto per il Sistema Produzione Animale in Ambiente Mediterraneo, Traversa La Crucca 3, località Baldinca, 07100 Sassari, Italy;l.sulas@cspm.ss.cnr.it(*correspondingauthor); gianni.re@ispaam.cnr.it; msalis@uniss.it

${ }^{2}$ Universitàdi Sassari Dipartimento di Agraria, Sezione di Scienze e Tecnologie Ambientali e Alimentari,Viale Italia 39,07100 Sassari, Italy; ggaran@uniss.it

33AgrisSardegna,Dipartimentoperla Ricerca nelleProduzioni Animali,07040 Olmedo, Italy; msitzia@agrisricerca.it; lzsalis@agrisricerca.it
\end{abstract}

\begin{abstract}
The legume's benefits are well-known and exploited in animal production systems, and the commercial availability of novel clover cultivars is an important opportunity for Mediterranean climatic areas. However, the successful performance of a legume species is strongly affected by the presence of specific rhizobia in the soil. The performances of 10 annual clover cultivars belonging to nine species, both uninoculated and inoculated, were compared at two locations in Sardinia (Italy). The rows $(2 \mathrm{~m}$ length each) were established in autumn and seed inoculation with a selected commercial rhizobial strain was performed at sowing. In the following spring, shoot length, the number of root nodules, shoot dry matter yield and nitrogen concentration were determined on complete recovered plants. Inoculation affected shoot length, with significant differences at each site. It ranged from 7.9 to $39.7 \mathrm{~cm}$. The average shoot DM production in the two locations ranged from 0.21 to $1.92 \mathrm{~g}$ per plant and there was a significant interaction of the location $\mathrm{x}$ cultivar. Inoculation significantly increased the growth of four cultivars. However, a cultivar selected in Sardinia, Trifolium brachycalycinum 'Antas', was irrespective of both location and inoculation, producing more shoot DM per plant than did the other clovers (about $1.80 \mathrm{~g}$ per plant). The results demonstrated that the clover agronomic performances differed among cultivars and locations. In addition, they highlighted that inoculation with a selected rhizobial strain is very useful for some clovers, suggesting that is preferable to ascertain at each site the need for clover inoculation.
\end{abstract}

Keywords: dry matter, legumes, rhizobial strain, root nodules, symbiosis, Trifolium

\section{Introduction}

Overall legume benefits, such as nitrogen fixation capacity, high nutritive value and voluntary feed intake, persistency, etc., are known and economically exploited in the animal production systems (Rochon et al., 2004; Frame, 2005). Forage and pasture legumes are basic components of production systems in areas with Mediterranean-type climate (Sulas, 2005). In addition to the well-known subterranean clover and annual medic cultivars, a second generation of annual pasture legumes has been developed in southern Australia, for both domestic use and seed export (Nichols et al., 2007). These cultivars belong to different genera, such as Biserrula, Ornithopus and Trifolium, and have a strong impact on the profitability and sustainability of southern Australian farming systems (Loi et al., 2005). Second generation forage legumes also include commercial varieties from new clover species, such as gland clover (Trifolium glanduliferum Boiss.), eastern star clover ( $T$. dasyurum $\mathrm{C}$. Presl), bladder clover (T. spumosum L.), and/or improved varieties of arrowleaf clover (T. vesiculosum Savi), Persian clover (T. resupinatum L.), etc. (Nichols et al., 2007). In meantime, the release of such novel cultivars represents an important opportunity for the remaining Mediterranean climatic areas of the world, where these cultivars are now commercially available to be utilised for fodder and/or multiple purposes, both in pure swards and in mixtures (Ovalle et al., 2010; Porqueddu et al., 2010; Sulas, 2005). In fact, annual legumes have the potential to be utilised in a range of environmental conditions and farming systems of Mediterranean areas because of the large number of species and their relevant diversity. 
166

However, the successful performance of a legume species depends on the presence of their specific $\mathrm{N}$-fixing root nodule bacteria (rhizobia) in the soil. In this sense, a suitable matching of both plant and bacterial genotypes is crucial for the development of an effective $\mathrm{N}$-fixing symbiosis (Howieson, 1999). Despite the co-evolution of legumes and rhizobia in the Mediterranean basin, there is evidence that this relationship is not always optimal in terms of $\mathrm{N}$-fixation, even if in the presence of background populations of rhizobia (Garau et al., 2005; Howieson et al., 2000; Terpolilli et al., 2008). Rhizobia are widespread according to the natural presence or cultivation of legume species (Amarger, 2001). On this regard, it is very important to evaluate if and where seed inoculation with selected bacterial inocula (i.e., the agricultural practice aimed at supplying the bacterial microsymbionts to the legume seed at sowing) is necessary (Date, 2001; Deaker et al., 2004; Howieson et al., 2005). Increased attention has also been paid to the rhizobia role in order to extend the cultivation areas of legumes in new environments (Sulas et al., 1998) and optimizing legume yields by the selection of superior $\mathrm{N}$-fixing strains capable of more effective symbioses (Amarger, 2001; Herridge et al., 2002). In spite of the relevant potential benefits from legume inoculation, very little information is available regarding the actual symbiotic requirements of second-generation legume cultivars established and grown in southern European regions.

Within the framework of a general assessment of second generation forage legumes carried out in Sardinia (Italy), the specific aims of this work were (i) to evaluate the growth, nodulation, forage and $\mathrm{N}$ yields of 10 annual clover cultivars, and (ii) to ascertain the role and the agronomic effects of clover inoculation with a selected Australian rhizobial strain.

\section{Materials and methods}

\section{Location, experimental design and crop management}

The research was carried out from autumn 2009 to spring 2010 at two locations in Sardinia (Italy): Bolotana and Olmedo. These two sites differed in terms of soil characteristics (Table 1) and field history. The former location has a sub-acid soil with a lower content of soluble phosphorus and a higher content of exchangeable potassium than does the latter, where soil is subalkaline. Moreover, in Bolotana, the soil has been left uncultivated for the last 40 years, and the annual clovers were never sown. In the soil of Olmedo, cereals and annual legumes were grown in the recent years. Ten commercial cultivars belonging to nine Trifolium species were compared at both locations. The list of clover species and cultivars, and some detailed information regarding the germplasm origin, cultivar selection and release, are reported in Table 2. The clover cultivars were established at both locations in October 2009, after soil ploughing and seedbed preparation, and according to the sowing rates recommended for these species (ranging from 0.6 to $1.6 \mathrm{~g} \mathrm{~m}^{-1}$ ). Before sowing, soil was fertilised with $100 \mathrm{~kg} \mathrm{ha}^{-1}$ of $\mathrm{P}_{2} \mathrm{O}_{5}$, using triple superphosphate. The 10

Table 1. Main soil and climatic characteristics of the two experimental locations

\begin{tabular}{|c|c|c|c|c|}
\hline \multirow[t]{2}{*}{ Parameters } & \multicolumn{4}{|c|}{$\begin{array}{l}\text { Location in Sardinia, } \\
\text { Italy }\end{array}$} \\
\hline & \multicolumn{2}{|c|}{ Bolotana } & \multicolumn{2}{|c|}{ Olmedo } \\
\hline Latitude, Longitude & $40^{\circ} 16$ & $\mathrm{~N}, 8^{\circ} 58^{\prime} \mathrm{E}$ & $40^{\circ} 4$ & ${ }^{\prime} \mathrm{N}, 8^{\circ} 22^{\prime} \mathrm{E}$ \\
\hline Altitude (a.s.l.) & \multicolumn{2}{|c|}{200} & \multicolumn{2}{|c|}{40} \\
\hline Soil series (FAO, 2006) & \multicolumn{2}{|c|}{ Eutric, Mollic Fluvisols } & \multicolumn{2}{|c|}{ Haplic Lixisol } \\
\hline Sand/Silt/Clay (\%) & \multicolumn{2}{|c|}{$68 / 12 / 20$} & \multicolumn{2}{|c|}{$50 / 23 / 27$} \\
\hline $\mathrm{pH}$ & \multicolumn{2}{|c|}{6.1} & \multicolumn{2}{|c|}{7.8} \\
\hline Organic $\mathrm{C}\left(\mathrm{g} \mathrm{kg}^{-1}\right)$ & \multicolumn{2}{|c|}{10.0} & \multicolumn{2}{|r|}{9.5} \\
\hline Total N $\left(\mathrm{g} \mathrm{kg}^{-1}\right)$ & \multicolumn{2}{|c|}{0.7} & \multicolumn{2}{|r|}{0.9} \\
\hline Assimilable P (mg kg $\left.{ }^{-1}\right)$ & \multicolumn{2}{|c|}{3.5} & \multirow{2}{*}{\multicolumn{2}{|c|}{7.3}} \\
\hline Exchangeable $\mathrm{K}\left(\mathrm{mg} \mathrm{kg}^{-1}\right)$ & \multicolumn{2}{|c|}{141.6} & 81.7 & \\
\hline Climate & $\begin{array}{c}\text { Climatic } \\
\text { mean }\end{array}$ & $2009-2010$ & $\begin{array}{c}\text { Climatic } \\
\text { mean }\end{array}$ & $2009-2010$ \\
\hline Min temperature $\left({ }^{\circ} \mathrm{C}\right)$ & 9.4 & 10.3 & 11.5 & 9.6 \\
\hline Max temperature $\left({ }^{\circ} \mathrm{C}\right)$ & 23.5 & 24.7 & 20.4 & 21.1 \\
\hline Rainfall (mm) & 580 & 528 & 582 & 752 \\
\hline
\end{tabular}

cultivars were manually sowed in $2 \mathrm{~m}$ length rows (with $1 \mathrm{~m}$ pathway between each row), either uninoculated or inoculated with the current Australian commercial inoculant strain for clovers (Rhizobium leguminosarum bv. trifolii, group C, strain WSM 1325), which was kindly provided by the Department of Agriculture and Food of Western Australia. Inoculation was performed using a peat-slurry inoculant as described by Yates et $\mathrm{al}$. (2010). No fertiliser or herbicide was applied after sowing. The experimental design was a randomised block with three replications. Plant emergence was recorded one week after sowing and it was regular. In spring 2010, about 150 days after sowing (corresponding to start to early flowering stage for most of clovers), a representative sample along the row containing plants $(30 \mathrm{~cm}$ length), plus a sample of soil (30 cm depth), was withdrawn. After immersing the samples in water and then gently washing them,

Table 2. Information on annual clover cultivars imported from Australia

\begin{tabular}{|c|c|c|c|c|c|}
\hline $\begin{array}{l}\text { Species and } \\
\text { cultivar }\end{array}$ & $\begin{array}{l}\text { Species common } \\
\text { name }\end{array}$ & $\begin{array}{l}\text { Native** } \\
\text { in Sardinia }\end{array}$ & $\begin{array}{c}\text { Germplasm origin of } \\
\text { cultivar }\end{array}$ & $\begin{array}{l}\text { Selection and } \\
\text { release }\end{array}$ & References \\
\hline T. dasyurum C.Presl'Sothis* & eastern star clover & no & Greece & Australia & Loi et al., 2007 \\
\hline T. glanduliferum Boiss. 'Prima" & gland clover & no & Israel & Australia & Nutt and Loi, 2002 \\
\hline T. hirtum All.'Hykon’ & rose clover & no & Mediterranean basin & Australia & Bailey, 1966 \\
\hline T.michelianum Savi 'Paradana' & balansa clover & yes & Mediterranean basin Turkey & Australia & Anon., 1999 \\
\hline T. resupinatum L. 'Prolific' & Persian clover & yes & Turkey & - & Snowball andEvans, 1998 \\
\hline T.resupinatum L . Turbo Plus' & Persian clover & yes & Mediterranean basin & $\begin{array}{l}\text { South } \\
\text { Australia }\end{array}$ & Belair Technology Pty Ltd, 2004 \\
\hline T. brachycalycinum Katzn. et Morley 'Antas' & subterranean clover & yes & Sardinia & Italy & Piano et al. 1997 \\
\hline T. subterraneum L. 'Denmark' & subterranean clover & yes & Sardinia & Australia & Oram, 1992 \\
\hline T.spumosum L. 'Bartolo'* & bladder clover & yes & Cyprus & Australia & Loi et al., 2008 \\
\hline T. vesiculosum Savi Zulu* & arrowleaf clover & no & Southern Europe & South Africa & - \\
\hline
\end{tabular}

${ }^{*}$ The first cultivar commercially available for the species; ${ }^{* *}$ According to Pignatti (1982) 
Table 3. Shoot lengths $(\mathrm{cm})$ of uninoculated $(\mathrm{U})$ and inoculated (I) clovers at the two locations

\begin{tabular}{|c|c|c|c|c|c|c|c|}
\hline \multirow{2}{*}{$\begin{array}{l}\text { Location } \\
\text { Species and cultivar }\end{array}$} & \multicolumn{3}{|c|}{ Bolotana } & \multicolumn{3}{|c|}{ Olmedo } & \multirow{2}{*}{$\mathrm{LxC}$} \\
\hline & $\mathrm{U}$ & $\mathrm{I}$ & & $\mathrm{U}$ & I & & \\
\hline T. dasyurum 'Sothis' & $21.2 \mathrm{de}$ & $26.3 \mathrm{bc}$ & ns & $35.5 \mathrm{a}$ & $39.7 \mathrm{a}$ & ns & *** \\
\hline T. glanduliferum 'Prima' & $28.6 \mathrm{ab}$ & $29.9 \mathrm{ab}$ & $*$ & $23.5 \mathrm{~cd}$ & $27.9 \mathrm{~cd}$ & ns & ns \\
\hline T. hirtum 'Hykon' & $25.0 \mathrm{bd}$ & $22.7 \mathrm{c}$ & ns & $23.1 \mathrm{~cd}$ & $31.2 \mathrm{c}$ & ns & $\mathrm{ns}$ \\
\hline T. michelianum 'Paradana' & $24.6 \mathrm{bd}$ & $34.0 \mathrm{a}$ & ns & $23.3 \mathrm{~cd}$ & $31.2 \mathrm{c}$ & ns & ns \\
\hline T. resupinatum 'Prolific' & $22.5 \mathrm{~cd}$ & $25.6 c$ & $*$ & $33.9 \mathrm{ab}$ & $33.2 \mathrm{bc}$ & ns & *** \\
\hline T. resupinatum 'Turbo Plus' & $16.5 \mathrm{ef}$ & $23.3 c$ & $*$ & $29.2 \mathrm{ab}$ & $37.4 \mathrm{ab}$ & $*$ & *** \\
\hline T. brachycalycinum 'Antas' & $33.1 \mathrm{a}$ & $32.8 \mathrm{a}$ & ns & $20.3 \mathrm{~cd}$ & $25.0 \mathrm{~d}$ & * & *** \\
\hline T. subterraneum 'Denmark' & $28.8 \mathrm{bc}$ & $24.7 \mathrm{c}$ & ns & $7.9 \mathrm{e}$ & $11.2 \mathrm{f}$ & ns & *** \\
\hline T. spumosum 'Bartolo' & $14.6 f$ & $17.6 \mathrm{~d}$ & * & $25.4 \mathrm{~cd}$ & $25.6 \mathrm{~d}$ & ns & *** \\
\hline T. vesiculosum 'Zulu' & $27.9 \mathrm{~b}$ & $30.4 \mathrm{a}$ & ns & 15.0de & $19.8 \mathrm{e}$ & ns & $* * *$ \\
\hline Average & 24.1 & 26.7 & & 23.7 & 28.2 & & \\
\hline \multirow[t]{2}{*}{$\mathrm{CV} \%$} & 11.6 & 8.3 & & 22.8 & 10.1 & & \\
\hline & \multicolumn{2}{|r|}{$\mathrm{P}$} & $\mathrm{P}$ & \multicolumn{2}{|c|}{$P$} & & \\
\hline Cultivar & \multirow{2}{*}{\multicolumn{2}{|c|}{$\begin{array}{l}* * * \\
* * *\end{array}$}} & & \multicolumn{2}{|c|}{$* * *$} & & \\
\hline Inoculation & & & & \multicolumn{2}{|c|}{$* * *$} & & \\
\hline Cultivar $\mathrm{x}$ Inoculation & \multicolumn{2}{|r|}{$* *$} & & \multicolumn{2}{|c|}{ ns } & & \\
\hline Location & & & ns & & & & \\
\hline Location $\mathrm{x}$ Inoculation & & & ns & & & & \\
\hline
\end{tabular}

Table 4. Root nodules (no. per plant) of uninoculated (U) and inoculated (I) clovers at the two locations

\begin{tabular}{|c|c|c|c|c|c|c|c|}
\hline \multirow{2}{*}{$\begin{array}{l}\text { Location } \\
\text { Species and cultivar }\end{array}$} & \multicolumn{3}{|c|}{ Bolotana } & \multicolumn{3}{|c|}{ Olmedo } & \multirow{2}{*}{$\mathrm{LxO}$} \\
\hline & $\mathrm{U}$ & I & & $\mathrm{U}$ & $\mathrm{I}$ & & \\
\hline T. dasyurum 'Sothis' & $12.3 \mathrm{~d}$ & $14.0 \mathrm{~cd}$ & * & $16.0 \mathrm{ac}$ & $19.0 \mathrm{~b}$ & ns & ns \\
\hline T. glanduliferum 'Prima' & $6.0 \mathrm{e}$ & $9.0 \mathrm{~d}$ & $\mathrm{~ns}$ & $5.7 \mathrm{~d}$ & $9.3 \mathrm{~cd}$ & ns & ns \\
\hline T. hirtum 'Hykon' & $13.0 \mathrm{~cd}$ & $11.7 \mathrm{~cd}$ & ns & $14.7 \mathrm{bc}$ & $16.7 \mathrm{~b}$ & ns & ns \\
\hline T. michelianum 'Paradana' & $17.7 \mathrm{bc}$ & $18.7 \mathrm{ab}$ & ns & $14.7 \mathrm{bc}$ & $18.7 \mathrm{~b}$ & ns & ns \\
\hline T. resupinatum 'Prolific' & $13.0 \mathrm{~cd}$ & $15.7 \mathrm{bc}$ & ns & $22.7 \mathrm{a}$ & $21.0 \mathrm{~b}$ & ns & ** \\
\hline T. resupinatum 'Turbo Plus' & 11.0de & $19.0 \mathrm{ab}$ & ns & $20.0 \mathrm{ab}$ & $40.3 a$ & $*$ & *** \\
\hline T. brachycalycinum 'Antas' & $20.3 b$ & $25.0 \mathrm{a}$ & ns & $13.0 \mathrm{bc}$ & $16.0 \mathrm{bc}$ & ns & $* *$ \\
\hline T. subterraneum 'Denmark' & $32.0 \mathrm{a}$ & $25.0 \mathrm{a}$ & ns & $14.0 \mathrm{bc}$ & $23.0 \mathrm{~b}$ & $*$ & *** \\
\hline T. spumosum 'Bartolo' & $8.7 \mathrm{de}$ & $11.7 \mathrm{~cd}$ & ${ }^{*}$ & $5.3 \mathrm{~d}$ & $8.0 \mathrm{~d}$ & ns & $\mathrm{ns}$ \\
\hline T. vesiculosum 'Zulu' & $8.3 \mathrm{de}$ & $7.7 \mathrm{~d}$ & ns & $8.7 \mathrm{~cd}$ & $8.3 \mathrm{~d}$ & ns & ns \\
\hline Average & 14.2 & 15.7 & & 13.5 & 18.0 & & \\
\hline \multirow[t]{2}{*}{$\mathrm{CV} \%$} & 19.7 & 22.2 & & 29.0 & 21.8 & & \\
\hline & \multicolumn{2}{|c|}{$\mathrm{P}$} & $\mathrm{P}$ & \multicolumn{2}{|c|}{$\mathrm{P}$} & & \\
\hline Cultivar & \multicolumn{2}{|c|}{$* * *$} & & \multicolumn{2}{|c|}{ *** } & & \\
\hline Inoculation & \multicolumn{2}{|c|}{ ns } & & \multicolumn{2}{|c|}{ *** } & & \\
\hline Cultivar $\mathrm{x}$ Inoculation & \multicolumn{2}{|c|}{ ns } & & \multicolumn{2}{|c|}{ ** } & & \\
\hline Location & & & ns & & & & \\
\hline Location $\mathrm{x}$ Inoculation & & & $\mathrm{ns}$ & & & & \\
\hline
\end{tabular}

In the column of locations, means followed by the same letter are not different at $\mathrm{P} \leq 0.05$ (Duncan's test).

In the rows, LSD test for seed inoculation effect in each cultivar inside the locations. The last column shows the location $\mathrm{x}$ cultivar interaction. ${ }^{*}=\mathrm{P} \leq 0.05,{ }^{* *}=\mathrm{P} \leq 0.01$, ${ }^{* * *}=\mathrm{P} \leq 0.001, \mathrm{~ns}=$ not significant.

complete plants with recoverable roots and root nodules (wet sieving) were separated. For each sample, shoot length and the number of root nodules were determined. Shoot sub-samples were dried in an oven-dryer at a temperature of $65^{\circ} \mathrm{C}$ to determinate the dry matter yield and its $\mathrm{N}$ concentration (Kjeldhal).

\section{Statistical analysis}

All data were analysed by GLM procedures using the SAS statistical package (SAS, 2002) with the factors species and location as fixed effects. Differences between clover cultivars in each location within inoculation treatments were assessed with Duncan's test for the separation of means $(P \leq 0.05)$ and the effect of the differences between inoculation treatments was evaluated within each location and species using a $L S D$ test $(P \leq 0.05)$. A P value of the interaction between the studied factors was also calculated.

\section{Results and discussions}

During the years 2009-2010, temperatures slightly differed from the long-term values at both sites (Table 1). Compared to the climatic values, the annual rainfall was 9\% lower and $28 \%$ higher in Bolotana and Olmedo, respectively. The annual rainfall in Olmedo was $220 \mathrm{~mm}$ higher than in Bolotana. 
Table 5. Shoot dry matter (g per plant) of uninoculated (U) and inoculated (I) clovers at the two locations

\begin{tabular}{|c|c|c|c|c|c|c|c|}
\hline \multirow{2}{*}{$\begin{array}{l}\text { Location } \\
\qquad \text { Species and cultivar }\end{array}$} & \multicolumn{3}{|c|}{ Bolotana } & \multicolumn{3}{|c|}{ Olmedo } & \multirow{2}{*}{$\mathrm{LxC}$} \\
\hline & $\mathrm{U}$ & $\mathrm{I}$ & & $\mathrm{U}$ & $\mathrm{I}$ & & \\
\hline T. dasyurum 'Sothis' & $0.39 \mathrm{c}$ & $0.63 b$ & * & $0.89 \mathrm{~b}$ & $1.22 b$ & ns & $* * *$ \\
\hline T. glanduliferum 'Prima' & $0.38 \mathrm{c}$ & $0.36 b$ & ns & $0.35 \mathrm{c}$ & $0.42 \mathrm{de}$ & ns & ns \\
\hline T. hirtum 'Hykon' & $0.45 \mathrm{c}$ & $0.41 b$ & ns & $0.62 b c$ & $0.82 \mathrm{c}$ & ns & * \\
\hline T. michelianum 'Paradana' & $0.58 c$ & $0.73 b$ & ns & $0.24 \mathrm{c}$ & $0.35 \mathrm{e}$ & ns & * \\
\hline T. resupinatum 'Prolific' & $0.24 \mathrm{c}$ & $0.33 b$ & ns & $0.58 \mathrm{bc}$ & $0.71 \mathrm{~cd}$ & ns & $*$ \\
\hline T. resupinatum 'Turbo Plus' & $0.21 \mathrm{c}$ & $0.45 b$ & * & $0.56 b c$ & $1.24 \mathrm{~b}$ & * & *** \\
\hline T. brachycalycinum 'Antas' & $1.79 \mathrm{a}$ & $1.85 \mathrm{a}$ & ns & $1.92 \mathrm{a}$ & $1.68 \mathrm{a}$ & ns & ns \\
\hline T. subterraneum 'Denmark' & $1.12 \mathrm{~b}$ & $0.77 b$ & * & $0.34 \mathrm{c}$ & $0.88 \mathrm{c}$ & * & * \\
\hline T. spumosum 'Bartolo' & $0.44 \mathrm{c}$ & $0.62 b$ & ns & $0.39 \mathrm{bc}$ & $0.57 \mathrm{ce}$ & ns & ns \\
\hline T. vesiculosum 'Zulu' & $0.45 c$ & $0.61 b$ & * & $0.24 \mathrm{c}$ & $0.47 \mathrm{de}$ & * & ns \\
\hline Average & 0.60 & 0.68 & & 0.61 & 0.84 & & \\
\hline \multirow[t]{2}{*}{$\mathrm{CV} \%$} & 40.16 & 33.48 & & 42.98 & 21.32 & & \\
\hline & \multicolumn{2}{|c|}{$\mathrm{P}$} & P & \multicolumn{2}{|c|}{$\mathrm{P}$} & & \\
\hline Cultivar & \multicolumn{2}{|c|}{ *** } & & \multicolumn{2}{|c|}{ *** } & & \\
\hline Inoculation & \multicolumn{2}{|c|}{ ns } & & \multicolumn{2}{|c|}{ ** } & & \\
\hline Cultivar $\mathrm{x}$ Inoculation & \multicolumn{2}{|c|}{ ns } & & \multicolumn{2}{|c|}{ ns } & & \\
\hline Location & & & ns & & & & \\
\hline Location $\mathrm{x}$ Inoculation & & & ns & & & & \\
\hline
\end{tabular}

In the rows, LSD test for seed inoculation effect in each cultivar inside the locations. The last column shows the location $\mathrm{x}$ cultivar interaction.

${ }^{*}=\mathrm{P} \leq 0.05,{ }^{* *}=\mathrm{P} \leq 0.01,{ }^{* * *}=\mathrm{P} \leq 0.001, \mathrm{~ns}=$ not significant.

\section{Shoot length}

The statistical analysis did not show significant differences between the sites (Table 3). On the contrary, the interaction between the location $\mathrm{x}$ cultivar was significant, as highlighted by the greater shoot length of $T$. dasyurum 'Sothis', $T$. resupinatum 'Turbo Plus' and 'Prolific', and T. spumosum 'Bartolo' grown in Olmedo, and by T. brachycalycinum 'Antas', T. subterraneum 'Denmark' and T. vesciculosum 'Zulu' in Bolotana.

In many instances, inoculation significantly affected shoot length at both sites. In the Bolotana site, the average lengths were $24.1 \mathrm{~cm}$ and $26.7 \mathrm{~cm}$ for uninoculated and inoculated plants, respectively, whereas in Olmedo, they were 23.7 and $28.2 \mathrm{~cm}$. The significant shoot length increases due to inoculation are summarised in Fig. 1. In Bolotana, the inoculated plants of $T$. glanduliferum 'Prima', T. resupinatum 'Prolific' and 'Turbo Plus' and T. spumosum 'Bartolo' showed a significantly greater shoot length compared to the uninoculated plants. In this site, greater lengths were observed in T. michelianum 'Paradana' $(34.0 \mathrm{~cm})$, T. brachycalycinum 'Antas' and T. vesciculosum 'Zulu' $(30.4 \mathrm{~cm})$ for the inoculated treatment, whereas with regard to the uninoculated treatment, T. brachycalycinum 'Antas' showed the greater shoot length. In Olmedo, the shoot length of $T$. resupinatum 'Turbo Plus' and T. brachycalycinum 'Antas' was significantly affected by inoculation, while greater lengths were observed in inoculated $T$. dasyurum 'Sothis' plants, which reached almost $40 \mathrm{~cm}$ and $T$. resupinatum 'Turbo Plus' (37.4 $\mathrm{cm})$.

\section{Root nodulation}

The number of root nodules per plant did not significantly differ between the locations and the interaction of the location $\mathrm{x}$ inoculant was also not significant (Table 4). However, in different cases the interaction of the location $\mathrm{x}$ cultivar was significant. Overall, T. resupinatum 'Turbo Plus' and 'Prolific' roots exhibited a significantly greater number of nodules in Olmedo, whereas $T$. subterraneum 'Denmark' and $T$. brachycalycinum 'Antas' had the higher number of nodules in Bolotana. Significant differences in the number of nodules per plant of clover cultivars were highlighted within the location and inoculation treatment. In Bolotana, inoculation caused a significant increase in the number of nodules per plant in $T$. dasyurum 'Sothis' and T. spumosum 'Bartolo'. On average, the number of root nodules per plant ranged from 6 to 32 in the uninoculated plants and between 9 and 25 in the inoculated plants. In the former, $T$. glanduliferum 'Prima' produced the lowest number of nodules per plant, whereas $T$. subterraneum 'Denmark' produced the highest. Inoculated plants of $T$. subterraneum 'Denmark' and T. brachycalycinum 'Antas' showed the highest number of root nodules per plant. In Olmedo, the inoculation caused a significant increase in the number of nodules per plant for T. subterraneum 'Denmark', and T. resupinatum 'Turbo Plus'. The latest cultivar doubled the number of nodules per plant compared to the uninoculated plants. In this location, uninoculated plants showed values

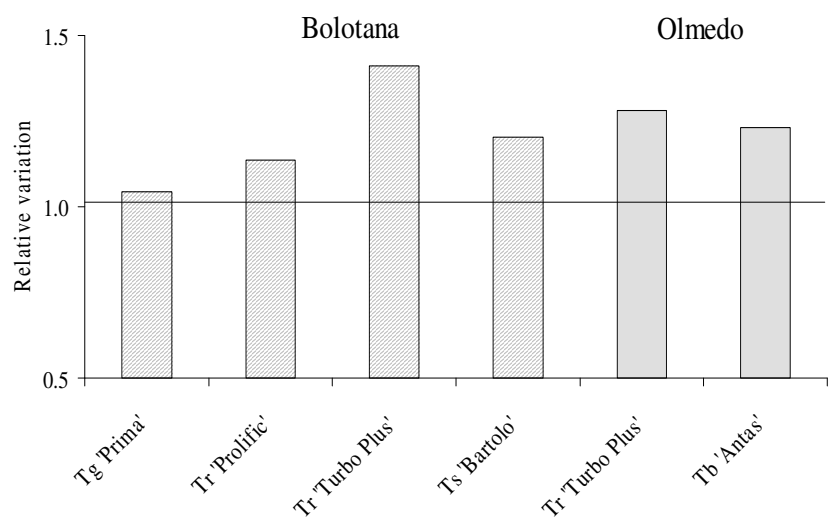

Fig. 1. Significant variation in shoot length ( $\mathrm{P} \leq 0.05$, LSD test) of inoculated clover plants at Bolotana and Olmedo. Value 1 is the baseline for shoot lengths of uninoculated plants 
Table 6. Shoot nitrogen (mg per plant) of uninoculated (U) and inoculated (I) clovers at the two locations

\begin{tabular}{|c|c|c|c|c|c|c|c|}
\hline \multirow{2}{*}{$\begin{array}{l}\text { Location } \\
\text { Species and cultivar }\end{array}$} & \multicolumn{2}{|c|}{ Bolotana } & \multicolumn{3}{|c|}{ Olmedo } & & \multirow{2}{*}{$\mathrm{LxC}$} \\
\hline & $\mathrm{U}$ & $\mathrm{I}$ & & $\mathrm{U}$ & I & & \\
\hline T. dasyurum 'Sothis' & $7.33 c$ & $11.96 \mathrm{bc}$ & * & $20.42 b$ & $28.91 \mathrm{c}$ & ns & *** \\
\hline T. glanduliferum 'Prima' & $6.89 \mathrm{c}$ & $6.45 c$ & ns & $8.64 \mathrm{~b}$ & $10.52 \mathrm{ef}$ & ns & ns \\
\hline T. hirtum 'Hykon' & $8.52 \mathrm{c}$ & $7.79 \mathrm{c}$ & ns & $17.29 b$ & $20.82 \mathrm{ce}$ & ns & ** \\
\hline T. michelianum 'Paradana' & $12.19 \mathrm{c}$ & $15.37 \mathrm{bc}$ & ns & $5.70 b$ & $9.02 \mathrm{f}$ & ns & ns \\
\hline T. resupinatum 'Prolific' & $5.19 \mathrm{c}$ & $7.22 \mathrm{c}$ & ns & $15.45 b$ & $19.44 \mathrm{ce}$ & ns & ** \\
\hline T. resupinatum 'Turbo Plus' & $5.55 \mathrm{c}$ & $11.74 \mathrm{bc}$ & * & $17.83 \mathrm{~b}$ & $38.86 b$ & * & *** \\
\hline T. brachycalycinum 'Antas' & $39.42 \mathrm{a}$ & $40.69 a$ & ns & $51.48 \mathrm{a}$ & $49.45 \mathrm{a}$ & ns & ** \\
\hline T. subterraneum 'Denmark' & $28.08 b$ & $19.18 b$ & * & $8.91 b$ & $26.34 \mathrm{~cd}$ & * & ns \\
\hline T. spumosum 'Bartolo'* & $9.70 c$ & $13.67 \mathrm{bc}$ & ns & $10.86 b$ & $16.67 \mathrm{df}$ & ns & ns \\
\hline T. vesiculosum 'Zulu’* & $11.77 \mathrm{c}$ & $15.85 \mathrm{bc}$ & * & $6.53 b$ & $13.23 \mathrm{ef}$ & * & ns \\
\hline Average & 13.46 & 14.99 & & 17.63 & 23.33 & & \\
\hline \multirow[t]{2}{*}{ CV\% } & 39.94 & 33.20 & & 48.76 & 23.44 & & \\
\hline & \multicolumn{2}{|c|}{ P } & $P$ & \multicolumn{2}{|c|}{$\mathrm{P}$} & & \\
\hline Cultivar & \multicolumn{2}{|c|}{ *** } & & \multicolumn{2}{|c|}{ *** } & & \\
\hline Inoculation & \multicolumn{2}{|c|}{ ns } & & \multicolumn{2}{|c|}{$* *$} & & \\
\hline Cultivar $\mathrm{x}$ Inoculation & \multicolumn{2}{|c|}{ ns } & & \multicolumn{2}{|c|}{ ns } & & \\
\hline Location & & & * & & & & \\
\hline Location $\mathrm{x}$ Inoculation & & & ns & & & & \\
\hline
\end{tabular}

In the column of locations, means followed by the same letter are not different at $\mathrm{P} \leq 0.05$ (Duncan's test).

In the rows, LSD test for seed inoculation effect in each cultivar inside the locations. The last column shows the location $\mathrm{x}$ cultivar interaction.

${ }^{*}=\mathrm{P} \leq 0.05,{ }^{* *}=\mathrm{P} \leq 0.01,{ }^{* * *}=\mathrm{P} \leq 0.001, \mathrm{~ns}=$ not significant.

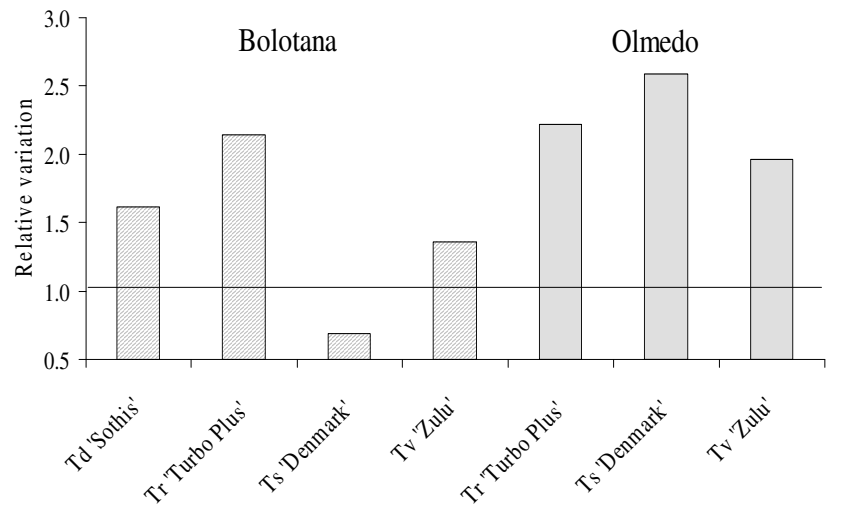

Fig. 2. Significant variation in shoot DM ( $\mathrm{P} \leq 0.05$, LSD test $)$ of inoculated clover plants at Bolotana and Olmedo. Value 1 is the baseline for shoot DM of uninoculated plants

ranging from 5.3 to 22.7 nodules per plant in $T$. spumosum 'Bartolo' and T. resupinatum 'Prolific', respectively and from 8 to 40.3 nodules per plant in the inoculated plants of $T$. spumosum 'Bartolo' and T. resupinatum 'Turbo Plus', respectively.

\section{Shoot dry matter}

The effect of location and the interaction of the cultivar $\mathrm{x}$ inoculation and the location $\mathrm{x}$ inoculant were not significant; however, significant interactions of the location $\mathrm{x}$ cultivar on shoot dry matter were recorded in many instances (Table 5). In fact, $T$. dasyurum 'Sothis', $T$. hirtum 'Hykon' and $T$. resupinatum 'Prolific' and 'Turbo Plus' produced significantly more DM per shoot in Olmedo, whereas T. michelianum 'Paradana' and T. subterraneum 'Denmark' produced a higher amount in Bolotana.

The inoculation positively affected the growth of $T$. subterraneum 'Denmark' in Olmedo and T. resupinatum 'Turbo Plus' in both locations and more than doubled the shoot DM (Fig. 2). Similarly, inoculated plants of $T$. dasyurum 'Sothis' in Bolotana and T. vesiculosum 'Zulu' in Olmedo had a considerable gain in dry matter production. On the other hand, T. subterraneum 'Denmark' grown in Bolotana, demonstrated a significantly decreased amount of shoot DM after rhizobial inoculation.

T. brachycalycinum 'Antas' produced much more shoot DM than did the other clover species (1.82 and 1.80 g per plant in Bolotana and Olmedo, respectively, as an average of uninoculated and inoculated plants), and it was irrespective of both location and inoculation treatment.

The less productive cultivars were T. resupinatum 'Prolific' and 'Turbo Plus' in Bolotana and T. vesiculosum 'Zulu' and $T$. michelianum 'Paradana' in Olmedo. The latter cultivar was confirmed to be less productive in inoculated plants too $(0.35 \mathrm{~g}$ per plant).

\section{Shoot nitrogen content}

On average, the $\mathrm{N}$ concentration was higher in Olmedo than in Bolotana (27.5 vs. $22.0 \mathrm{~g} \mathrm{~kg}^{-1} \mathrm{DM}$, respectively, $\mathrm{P}<0.001)$. In the same way, the average content of nitrogen in shoots (Table 6) showed higher quantities in Olmedo than in Bolotana (20.48 vs. $14.23 \mathrm{mg}$ per plant, respectively). In particular, five cultivars ( $T$. dasyurum 'Sothis', $T$. hirtum 'Hykon', T. resupinatum 'Prolific' and 'Turbo Plus' and T. brachycalycinum 'Antas') showed a higher shoot nitrogen content in plants grown in Olmedo than in Bolotana, as indicated by a high significant interaction of the location $\mathrm{x}$ cultivar (Table 6).

In Bolotana, T. dasyurum 'Sothis', T. resupinatum 'Turbo Plus' and T. vesiculosum 'Zulu' showed a significantly higher $\mathrm{N}$ content in the inoculated plants. On the contrary, and consistent with the results of DM production, T. subterraneum 'Denmark' demonstrated a smaller shoot nitrogen amount in inoculated plants than it did in the uninoculated plants, reaching $28.1 \mathrm{mg}$ per plant, which is twice the average value. In 
170

Olmedo, this cultivar had an opposite behaviour producing almost triple the nitrogen quantity in the inoculated plants ('Denmark', 26.3 mg per plant). This result was consistent with the recorded performances in terms of DM and the number of root nodules per plant. At the same site, plants of $T$. vesiculosum 'Zulu' and T. resupinatum 'Turbo Plus' gained more than twice the $\mathrm{N}$ content, and the latter was characterised by the highest $\mathrm{N}$ concentration in the shoots (on average, 31.4 $\mathrm{g} \mathrm{kg}^{-1} \mathrm{DM}$ ). The significant increases in shoot $\mathrm{N}$ content due to inoculation are summarised in Fig. 3.

Producing the highest content of DM in all treatments and locations, T. brachycalycinum 'Antas' had the highest content of nitrogen per shoot, with significant differences when compared to all other clovers. Finally, a positive significant linear regression $\left(R^{2}=0.55 ; P<0.001\right)$ was found between the number of nodules and the nitrogen content per plant, as highlighted in inoculated cultivars only (Fig. 4). The research allowed for elucidating agronomic performances in a wide range of clover cultivars and Trifolium species at two contrasting locations of Sardinia. Location affected the performances of several clover cultivars under comparison, as revealed by the significant interaction for the location $\mathrm{x}$ cultivar. In fact, $T$. dasyurum 'Sothis' and $T$. resupinatum 'Prolific' and 'Turbo Plus' produced more than twice the shoot DM in Olmedo than it did in Bolotana. In contrast, T. michelianum

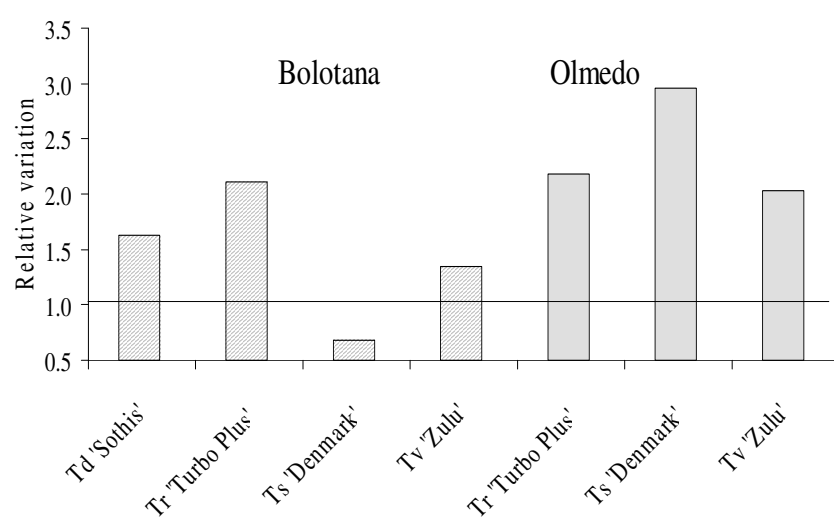

Fig. 3. Significant variation in shoot $N$ content $(P \leq 0.05$, LSD test $)$ of inoculated clover plants at Bolotana and Olmedo. Value 1 is the baseline for shoot $\mathrm{N}$ content of uninoculated plants

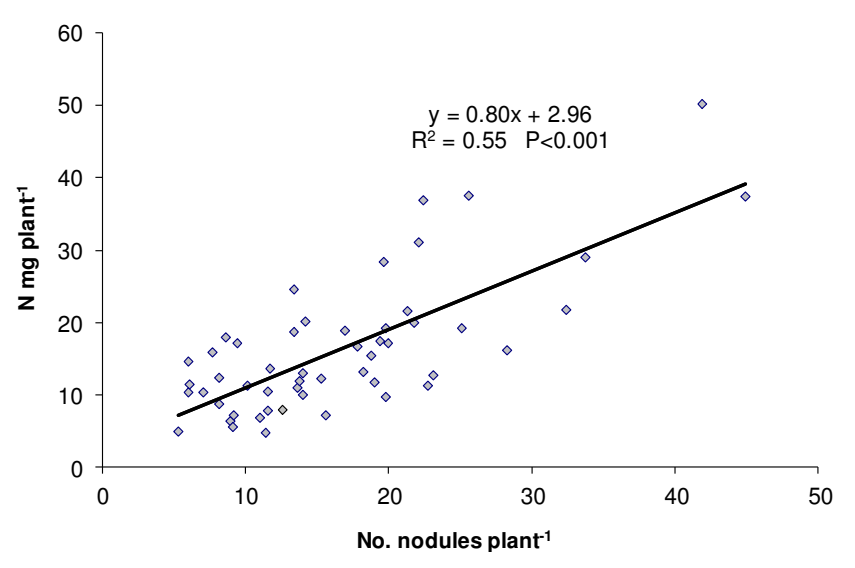

Fig. 4. Linear regression between the number of root nodules and shoot $\mathrm{N}$ content per plant in inoculated clovers
'Paradana' and T. subterraneum 'Denmark' produced considerably more DM in Bolotana than in Olmedo. Moreover, shoot length, root nodulation and shoot nitrogen content were also affected. These results could be attributed to the differences between sites for environmental characteristics that are mainly related to the edaphic conditions and climatic trends (Table 1).

At both locations, root nodulation was also recorded in uninoculated plants of all cultivars (Table 4). This result is not surprising and suggests (i) the presence of a native population of infective (i.e. capable of nodulation) Rhizobium leguminosarum bv. trifolii in both soils, and (ii) the very likely competition for nodule occupancy between the applied inoculant rhizobia and the indigenous bacterial populations (Brockwell et al., 1982). However, the locations are not similar regarding the natural distribution of annual clover species (Piano et al., 1982, 1997), and this may be a factor affecting the strain composition of autochthonous clover rhizobia (Graham, 2008). The aforementioned competition between inoculant strain and resident rhizobia also highlights the need of studies for strain fingerprinting and species identification in root nodule bacteria (Muresu et al., 2005), even if such activities are outside the scope of this paper. Despite the fact that most clover cultivars did not demonstrate improvements, some of them benefited from inoculation with the selected rhizobial strain. In four out of the 10 clovers, significant positive effects of inoculation were clearly detected. On the other hand, $T$. subterraneum 'Denmark' experienced decreased shoot DM when inoculated in Bolotana. However, these latter results could be explained because spontaneous $T$. subterraneum, absent in the Olmedo area and in soils with a similar $\mathrm{pH}$ value (Piano et al., 1982), is native and very common in natural pastures of Bolotana (Salis et al., 2013). Therefore, the presence in this location of highly effective and competitive populations of $R$. leguminosarum bv. trifolii adapted to T. subterraneum can be reasonably assumed. Importantly, this is supported mostly by nodulation data and shoot $\mathrm{N}$ content and may explain the poor results of the selected inoculant with $T$. subterraneum plants in Bolotana. Moreover, this is in agreement with recent findings indicating a large diversity in the symbiotic capacity of clovers with naturalised soil rhizobia in Spain (Ramirez-Bahena et al., 2009) and Australia (Drew et al., 2011). Overall, the different response to inoculation recorded at the two sites do not allow us to indicate an univocal effect of inoculation which mostly appeared species and cv. and site dependent.

Key factors and their interrelationships, even if they were not the aim of our experiment, could contribute to the explanation of the abovementioned outcomes. In fact, the different clover germplasm origins (Table 2), the clover species distribution in Sardinia (Piano et al., 1982), the occurrence of background rhizobia populations, the different edaphic conditions (Table 1) and the field history in the experimental locations could have affected the symbiotic performances of the investigated clovers.

It is worth noting that among the four clover cultivars belonging to species exotic to Sardinia, only two benefited from the inoculation, indicating an effective symbiosis with the selected strain. However, the native T. brachycalycinum 'Antas' (selected in Sardinia), had the best performance in terms of shoot DM and nitrogen yield at each location, yet was not affected by the inoculation. 
Taken together our data indicate a partial effectiveness of the commercial inoculant at our experimental conditions. This was due to the presence of resident rhizobial populations at both sites, which allowed clover plant growth without inoculation. In the case of $T$. subterraneum 'Denmark' in Bolotana, resident rhizobial populations also appeared significantly more effective in increasing DM and $\mathrm{N}$ yields. However, the positive regression between the number of nodules and the nitrogen content per plant highlighted in the inoculated cultivars could suggest a substantial contribution of the inoculant in development of active root nodules.

Unfortunately, comparisons with other results from similar experiments are not possible due to the overall lack of information for southern European Mediterranean areas, to our knowledge. Even if legume inoculation is a routine practice in other Mediterranean areas of the world, such as in south and Western Australia, comparisons with our results may be difficult to elucidate because annual clovers and related rhizobia are not native there. On the contrary, inoculation is very unusual in Sardinia, where several clover species are autochthonous. Our research contributes to clarify the role, in a southern European area, of a commercial rhizobial strain selected in Australia, indicating a sub-optimal performance of the selected strain with many of the tested clover cultivars. Interestingly, the plant selection is being considered as a potential tool to overcome sub-optimal $\mathrm{N}$ fixation associated with poorly effective soil rhizobia (Drew et al., 2011).

\section{Conclusions}

Environmental differences in the locations and seed inoculation with a commercial rhizobial strain affected growth and productive performances of the clover cultivars. In 4 out of the 10 cultivars under investigation, significant positive effects of inoculation with a group $\mathrm{C}$ inoculant were clearly detected. In fact, $T$. resupinatum 'Turbo Plus' and $T$. vesiculosum 'Zulu' produced more than twice the shoot DM in both locations, whereas $T$. dasyurum 'Sothis' and $T$. subterraneum 'Denmark' in a single location only, experienced a relevant DM gain caused by inoculation. However, the locally selected T. brachycalycinum 'Antas', irrespective of inoculation, showed the best performance in terms of shoot DM and nitrogen yield at both locations, highlighting its good adaptation ability, whereas inoculation significantly decreased the shoot DM in T. subterraneum 'Denmark' in the location where this clover species is very common as autochthonous plant. The results pointed out that, in our experimental conditions, seed inoculation with the selected rhizobial strain can be useful only for some clovers therefore suggesting a careful site-by-site evaluation of the inoculum effectiveness with different clover cultivars and possibly the need for superior inocula more adapted to our pedoclimatic environments.

\section{Acknowledgements}

Maddalena Sassu, Salvatore Nieddu, Daniele Dettori, Piero Saba and Anton Pietro Stangoni (CNR-ISPAAM) and Andrea Pintore, Salvatore Mastino, Gianfranco Becugna (AGRIS Sardegna) are acknowledged for their technical assistance.

\section{References}

Amarger N (2001). Rhizobia in the field. Adv Agron 73:109-168.

Anon. (1999). Paradana balansa clover, p. 165. In: Register of Australian Herbage Plant Cultivars. Oram RN (Ed). CSIRO, Australia.

Bailey ET (1966). Rose clover: Description, use, and varietal differences in rose clover in Western Australia. J Agric West Aust 7:170-175.

Belair Technology Pty Ltd (2004). Turbo Plus Persian clover. Plant Varieties Journal. Official Journal of Plant Breeder's Right Australia 17(3):55.

Brockwell J, Gault RR, Zorin M, Roberts MJ (1982). Effects of environmental variables on the competition between inoculum strains and naturalized populations of Rhizobium trifolii for nodulation of Trifolium subterraneum L. and on rhizobia persistence in the soil. Aust J Agr Res 33:803-815.

Date RA (2001). Advances in inoculant technology: A brief review. Aust J Exp Agr 41:321-325.

Deaker R, Roughley R, Kennedy I (2004). Legume seed inoculation technology - A review. Soil Biol Biochem 36:1275-1288.

Drew EA, Charman N, Dingemanse R, Hall E, Ballard RA (2011). Symbiotic performance of Mediterranean Trifolium spp. with naturalized soil rhizobia. Crop Pasture Sci 62:903-913.

FAO, ISSS and ISRIC (2006). World Reference Base for Soil Resources. A framework for international classification, correlation and communication. World Soil Resource Report n. 103. Rome: FAO.

Frame J (2005). Forage legumes for temperate grasslands. FAO, p. 309. Rome (Italy) and Science Publishers Inc. Enfield (USA).

Garau G, Reeve WG, Brau L, Yates RJ, James D, Tiwari R, O’Hara GW, Howieson J (2005). The symbiotic requirements of different Medicago spp. suggest the evolution of Sinorhizobium meliloti and $S$. medicae with hosts differentially adapted to soil $\mathrm{pH}$. Plant Soil 276:263-277.

Graham PH (2008). Ecology of root-nodule bacteria of legumes, p. 23-43. In: 'Nitrogen fixing leguminous symbioses'. Dilworth MJ, James EK, Sprent JI, Newton WE (Eds). Springer, Dordrecht.

Herridge D, Gemell G, Hartley E (2002). Legume inoculants and quality control. ACIAR Proc 109e:105-115.

Howieson JG (1999). The host-rhizobia relationship, p. 96-106. In: Bennett SJ, Cocks PS (Eds). Genetic Resources of Mediterranean Pastures and Forage Legumes. Kluver Academic Publishers, Netherlands.

Howieson JG, O'Hara GW, Loi A (2000). The legume-rhizobia relationship in the Mediterranean Basin. Cahiers Options Méditerranéennes 45:305-314.

Howieson JG, Yates RJ, O'Hara GW, Ryder M, Real D (2005). The interactions of Rhizobium leguminosarum biovar trifolii in nodulation of annual and perennial Trifolium spp. from diverse centres of origin. Aust J Exp Agr 45:199-207.

Loi A, Howieson JH, Nutt BJ, Carr SJ (2005). A second generation of annual pasture legumes and their potential for inclusion in Mediterranean-type farming systems. Aust J Exp Agr 45:289-299. 
172

Loi A, Nutt BJ, Revell CK (2008). AGWEST ${ }^{\circ}$ Bartolo bladder clover (Trifolium spumosum) A low cost annual pasture legume for Mediterranean mixed farming systems. Agribusiness Crop Updates, Burswood Entertainment complex, Perth.

Loi A, Nutt BJ, Revell CK, Snowball R (2007). AGWEST' Sothis: Trifolium dasyurum (Eastern star clover). Aust J Agr Res 47:15121515.

Muresu R, Sulas L, Polone E, Squartini A (2005). PCR primers based on different portions of insertion elements can assist phylogeny studies, strain fingerprinting and species identification in rhizobia. FEMS Microbial Ecol 54:445-453.

Nichols PGH, Loi A, Nutt BJ, Evans PM (2007). New annual and short-lived perennial pasture legumes for Australian agriculture 15 years of revolution. Field Crop Res 104:10-23.

Nutt BJ, Loi A (2002). Prima gland clover. Farmnote no. 4/2002, Department of Agriculture Western Australia, Perth, Australia.

Oram RN (1992). Register of Australian herbage plant cultivars. B. Legumes Clover. d. Trifolium subterraneum L. var. subterraneum (Katzn. et Morley) Zohary and Heller (subterranean clover) cv. Denmark. Aust J Exp Agr 32:539-540.

Ovalle C, del Pozo A, Fernández F. (2010). Arrowleaf clover (Trifolium vesiculosum savi): a new species of annual legumes for high rainfall areas of the Mediterranean climate zone of Chile. Chilean JAR 70:170-177.

Piano E, Pecetti L, Carroni AM (1997). Campeda, Limbara, Losa e Antas: The first Italian cultivars of subterranean clover (In Italian). Sementi elette 43:27-32.

Piano E, Sardara M, Pusceddu S (1982). Observations on the distribution and ecology of subterranean clover and other annual legumes in Sardinia. Rivista di Agronomia 16:273-283.

Pignatti S (1982). Flora of Italy (In Italian). Edagricoltura.

Porqueddu C, Franca A, Sulas L (2010). A second generation of pasture legumes: An opportunity for improving the biodiversity in farming systems of Mediterranean basin? Cahiers Options Méditerranéennes, Series A 92:241-245.
Ramírez-Bahena MH, Velazquez E, Fernandez-Santos F, Peix A, Martinez-Molina E, Mateos PF (2009). Phenotypic, genotypic, and symbiotic diversities in strains nodulating clover in different soils in Spain. Can J Microbiol 55:1207-1216.

Rochon JJ, Doyle CJ, Greef JM, Hopkins A, Molle G, Sitzia M, Scholefield D, Smith CJ (2004). Grazing legumes in Europe: A review of their status, management, benefits, research needs and future prospects. Grass Forage Sci 59:197-214.

Salis M, Canu S, Carroni AM, Sulas L (2013). Performances of spontaneous subterranean clover in Mediterranean natural pastures. Proc of the $17^{\text {th }}$ Meeting of the FAO-CIHEAM, Trivero, Italy, 184-187.

SAS (2002). SAS 9.0. Institute Inc., Cary, NC, USA.

Snowball R, Evans PM (1998). Register of Australian herbage plant cultivars Trifolium resupinatum L. cv. Persian Prolific. Aust J Exp Agr 38:323-324.

Sulas L (2005). The future role of forage legumes in the Mediterranean climatic areas, p. 29-54. In: Reynolds SG, Frame J (Eds). Grasslands: Developments Opportunities Perspectives. Rome, FAO, and New Hampshire, USA, Science Publishers.

Sulas L, Re GA, Loi A, Howieson JG (1998). The selection of optimal root-nodule bacteria inoculants increases the forage yield of Hedysarum coronarium (sulla). Proc of the 17th General Meeting of the EGF Debrecen, Hungary 899-904.

Terpolilli JJ, O'Hara GW, Tiwari RP, Dilworth MJ, Howieson JG (2008). The model legume Medicago truncatula A17 is poorly matched for N2 fixation with the sequenced microsymbiont Sinorbizobium meliloti 1021. New Phytol 179:62-66.

Yates R, Howieson JH, Revell C (2010). Inoculating pasture legumes. Farmnote no. 431/2010, Department of Agriculture and food of Western Australia, Perth, Australia. 